\title{
STRUCTURAL PROPERTIES OF THE NEOGENE EVAPORITE DEPOSITS IN THE SOUTH OF TUZGÖLÜ BASIN, TURKEY
}

DOI: http://dx.doi.org/10.18509/GBP.2017.01

UDC: 553.63:551.782(560)

\author{
Arif Delikan ${ }^{1}$ \\ Ayla Bozdağ ${ }^{1}$ \\ Necati Karakaya ${ }^{1}$ \\ Hatice Ercan 1,2 \\ Muazzez Çelik Karakaya ${ }^{1}$ \\ ${ }^{1}$ Selçuk University Engineering Faculty Geology Engineering, Konya, 42079, Turkey \\ ${ }^{2}$ Istanbul Technical University, Department of Geology, 34469, Istanbul, Turkey
}

\begin{abstract}
Tuzgölü Basin located at the Central Anatolia is an inner enclosed basin and is bounded by Ankara uplift in the north, the Kırşehir massif from in the east and the SivrihisarBozdağ massif from the west. The Salt Lake is bordered by Tuzgölü, Akşehir and Niğde fault zones in NE-GW direction. Typical mechanical and sedimentary structures in the evaporitic sediments are observed in especially gypsum and anhydrite, partially glauberite and halite deposits. The most prominent structures observed in the investigated cores are usually sequential sedimentation or stratification, other primary structures are slump structures, sub-strata traces, mud cracks and flat conglomeratic gravel sediments. Stratification in the evaporites showed changes in the mineralogical and textural properties from the bed to the bed. There are also settlement/load structures, ripple cross lamination and cross stratification were determined. As a result of sedimentation, sedimentation-grade bedding and intercalation of clay or carbonate mud and salted mineral mud have been observed. The lacustrine sediments in the inner zones of the basin consist of $\mathrm{Ca}-\mathrm{Na}$-sulphate, $\mathrm{Mg}$-sulphate sediments, claystone, carbonate alternation and partly laminated. Repeating the evaporitic sediments in $\mathrm{mm}$ and $\mathrm{cm}$ thickness provides a seasonal sedimentation view.
\end{abstract}

Keywords: Evaporite, halite, glauberite, Tuzgölü, Turkey

\section{INTRODUCTION}

The Tuz Gölü Basin is located in the south-eastern part of Central Anatolia (Figure 1). Evaporitic deposits are generally formed from $\mathrm{Na}, \mathrm{Ca}, \mathrm{Mg}, \mathrm{Cl}, \mathrm{CO} 3$, and $\mathrm{SO} 4$ in different contents and most of them were precipitated inner continental basin, tectonically active and arid lacustrine environments which effected time to time intake of seawater ([1], [2], [3]). In this study area, more thicknesses of salt and soda than a few hundred meters were deposited during Miocene period.

Taurus Mountains on the north and Salt Lake on the southwest boundaries to the study area which is an important inner basin located in the Central Anatolian (Figure 1). The basin is the Turkey's most important in terms of salt and soda deposits which have been mined more than five hundred years. Hence, a number of studies have been carried out in the study area for various purposes ([4], [5], [6], [7], [8], [9] and [10]). 
The aim of the study is to a) interpret origin of the evaporates, b) explain active processes in the basin by determining of structural and textural properties of the evaporates.

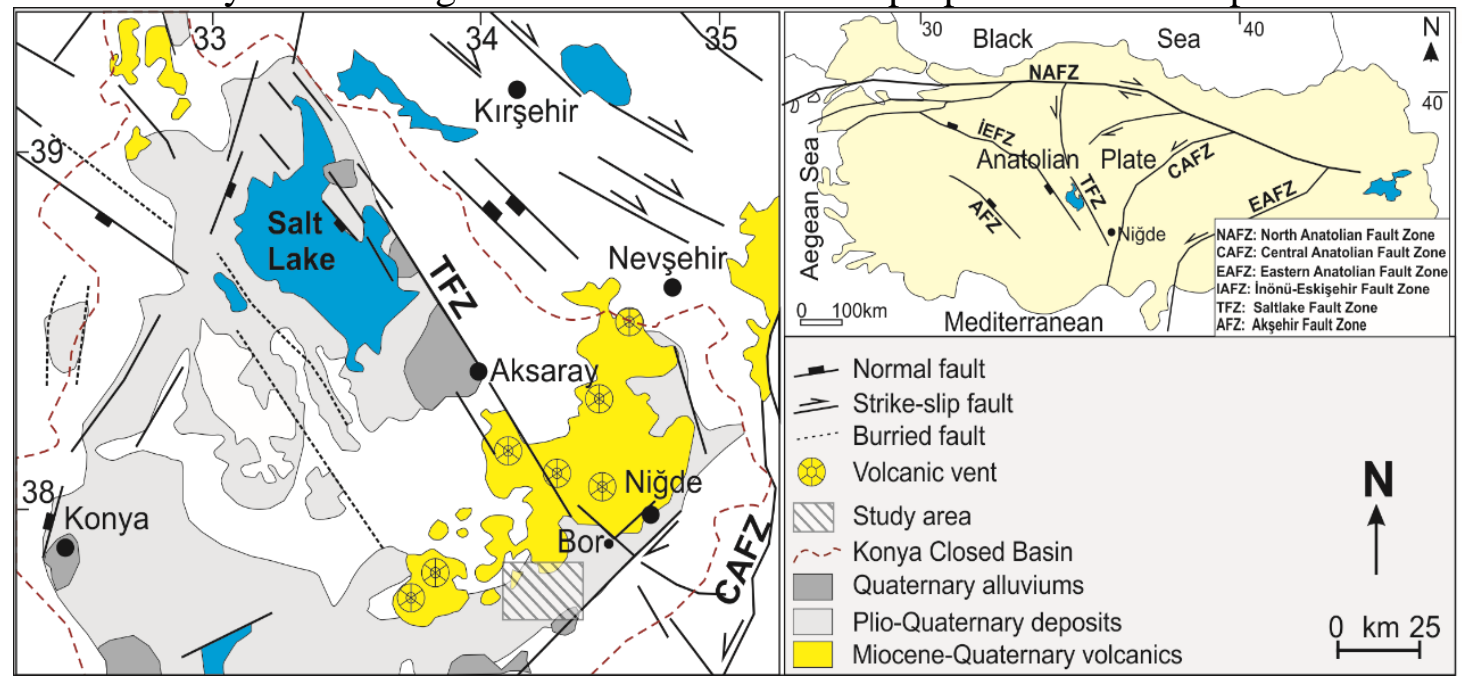

Figure 1. Simplified geology map (after [11] location map of study.

\section{GEOLOGY}

The study area is located in the southern part of the Tuz Gölü. Bedrocks of the study area consist of Paleozoic metamorphic (metaschist, metacarbonate, quartzite, schist, etc.) and Upper Cretaceous ultrabasic rocks. Andesitic and basaltic volcanoes, of various ages since from Miocene have been activated in the Basin (Figure 1). The most important tectonic lines in the region are right lateral Salt Lake fault extending in N-NW direction and the S-SW trending Ecemiş fault along the eastern boundary of the Lake Tuzgölü that borders of the inner basin. The basement of the basin is represented by Paleozoic aged rocks which consists of gneiss, quartzite, calc-schists and coarse crystalline white marbles. The basement unit is overlain unconformably by the Paleocene-Eocene-aged units consists of basaltic pillow lava, graded, bedded detrital sediments and volcanoclastics. The basin was an inner shallow marine character in the PaleoceneEocene period while it was a closed lake in the Miocene-Pliocene.

\section{RESULTS}

Halite, Na-Ca-sulfate minerals (anhydrite, gypsum, glauberite, eugasterite and thenardite), Mg-sulfate minerals (bloedite, epsomite, loweite), dolomite, magnesite and calcite minerals were determined in the basin as evaporite minerals. Typical mechanical and sedimentary structures in the evaporitic sediments are observed in especially gypsum and anhydrite, partially glauberite and halite deposits. The most prominent structures observed in the investigated cores are usually sequential sedimentation or stratification, other primary structures are slump structures, sub-strata traces, mud cracks and flat conglomeratic gravel sediments. Stratification in the evaporites showed changes in the mineralogical and textural properties from the bed to the bed. There are also settlement/load structures, ripple cross lamination and cross stratification were determined. As a result of sedimentation, sedimentation-grade bedding and intercalation of clay or carbonate mud and salted mineral mud have been observed (Figure 1). 

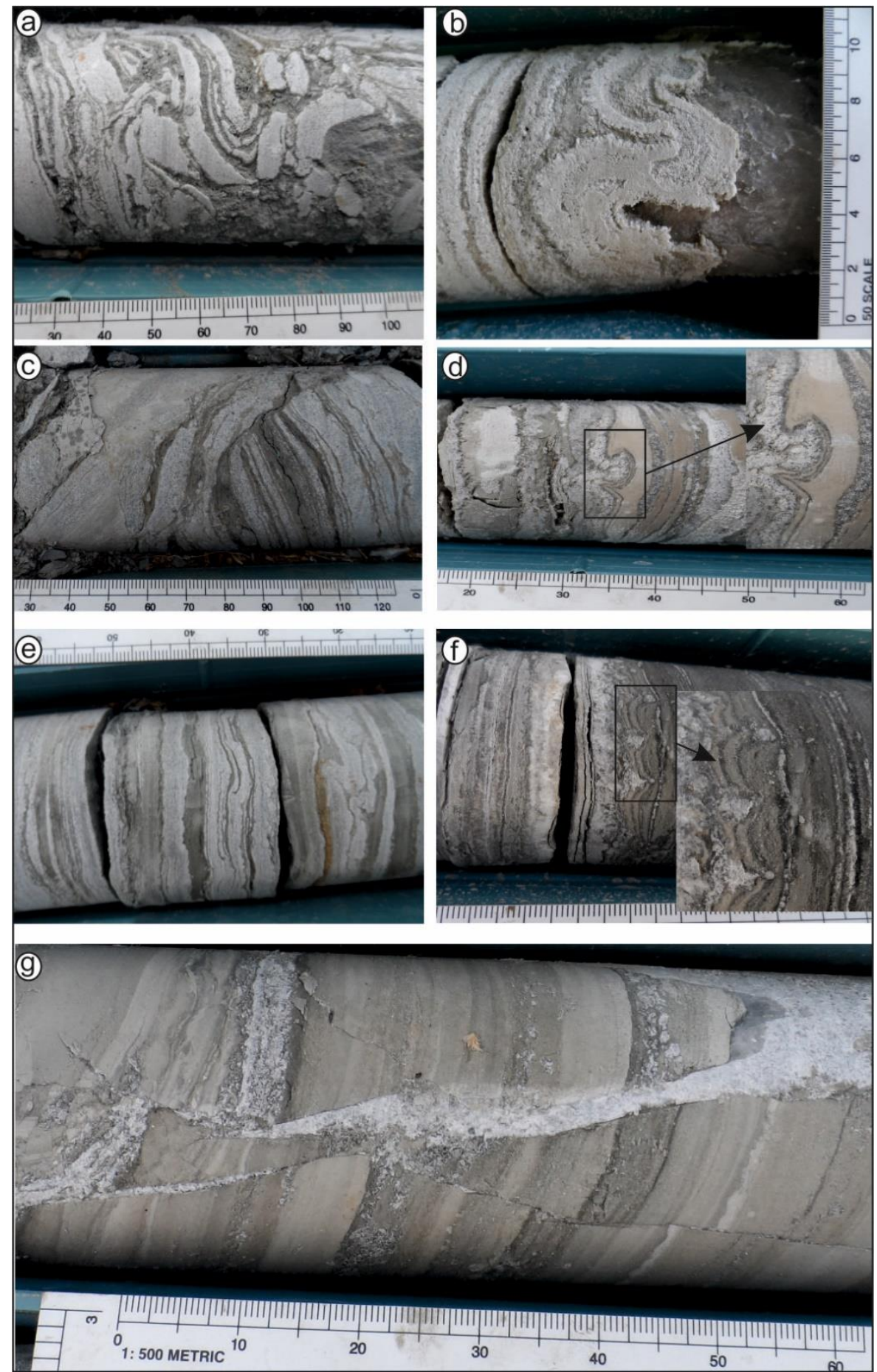

Figure 2. mechanical and sedimentary structures in the evaporitic sediments

a) Slump and breccia structures (471 m), b) Slump structure (700.2 m), c) tectonic deformation (466 m), d) slump structure (712.5 m), e) sequential sedimentation (543 m), f) ripple cross lamination (272 m), g) step-shaped micro fracture and/or crack $(758 \mathrm{~m})$.

The lacustrine siliceous limestone, which represents the center of the basin, is composed of claystone siltstone and partly sandstone and rarely matured alternation of polygenic conglomerates. The thickness of the clastic sediments decreases towards the basin edge. The presence of large clastic, conglomeratic deposits is sometimes associated with basin energy uptake. In addition, almost all the wells are reddish and greenish mudstones 
predominantly on the surface. At these levels, there are lenticular gypsum bands ranging in thickness from a few centimetres. Carbonate (dolomitic), clay lamination, greenish sandstone, siltstone, and again fibrous gypsum bands and gypsum / anhydrite nodules were observed at the middle levels of the drillings. Fibrous gypsum veins (satin spar) are usually parallel or semi-parallel to bedding. In dolomitic sediments, anhydrite nodules are mostly secondary and rarely primarily in the marginal and central parts of the basin. The lacustrine sediments in the inner zones of the basin consist of Ca-Na-sulphate (gypsum, anhydrite, glauberite, thenardite, mirabilite), $\mathrm{Mg}$-sulphate (epsomite, bloedite) sediments, claystone, carbonate (dolomite and magnesite) alternation and partly laminated. Repeating the evaporitic sediments in $\mathrm{mm}$ and $\mathrm{cm}$ thickness provides a seasonal sedimentation view. Among the halite deposits $(10-50 \mathrm{~cm})$, thin clay laminae and other sulphate minerals, especially glauberite massive or small-coarse crystalline deposits, were found to be massive anhydrite.

Based on the petrographic data obtained from drilling cores and correlations of ten drillings it is concluded that the precipitation of halite increases in the northern part of the basin while it decreases in the south may be indicating that there is a flowing of groundwater from the south to the basin. Depending on the detrital formation, the observation of erosional traces on the edges of individual selenitic gypsum crystals and the observation of lenticular gypsums parallel to bedding showed the presence of sedimentation alongside the basin in some areas. During the evaporation and afterwards, many deformations occurred in evaporation sediments that collapsed into the basin as a result of many tectonic activities in and around the basin. With the effect of tectonics, many micro-macroscopically (with log-to-log correlation) faults, conjugate cracks and fracture systems developed in the rocks. These fractures and cracks are mostly filled with halite, gypsum and clay-like material, which are usually observed in a massive and fibrous structure. In the layer and lamina in which the less consolidated gypsum, halite and anhydrite minerals are present, mostly limestone structures and accretion are observed while the clay and carbonate rocks are found in the laminates and strata. However, the fluidized salt formed flames between the other units to form the diapir and dome structures, while in some places formed the flowing slump structures on the surface of the layers. The cracks that formed in the evaporation of the water in the evaporitic mud flats were filled in the gypsum minerals that could be settled more easily in the next stage. Selenitic gypsum beds are usually observed in massive layers of several centimeters to several tens of meters thick, grey-brown laminated with shale/mudstones, and usually seen in the vertical direction, or in a resemblance to a lump of cauliflower. Microcrystalline gypsum is a type of alabaster gypsum formed by the combination of gypsum crystals in microscopic size. Microcrystalline gypsum was observed in the form of massive nodules, with sizes ranging from a few centimeters to decimeters and elongated or spheroidal shapes in the vertical / horizontal direction. Gypsum nodules sometimes showed cementing with more transparent gypsum and / or satin spar gypsum. It was also observed that the nodules were adjacent to each other. Sometimes, inter nodular spaces showed irregular / mildly folded laminae.

Anhydrite is also show nodules morphologies like to gypsum, the nodules are $2-5 \mathrm{~cm}$ in size and filled with dark-colored materials like clay and marl. Chicken wire or mosaic texture was observed in the cores where the sizes of the nodules were smaller. The nodular anhydrides were formed in semi-aqueous conditions. However, the nodular anhydrides can also form secondary crystal growths in overly salty water. Anhydrite laminae are interlaced with thick halite layers, giving occasionally the appearance of laminated halite 
formation. Sometimes it has been found especially at shallow depths where the laminated anhydrite nodules grow together and show a somewhat intestinal resemblance. Massivelooking anhydrite laminates, alternating with dolomite and sometimes with halite, are mostly observed in the deep sections of the basin. The rhythmic anhydrite, dolomite and shale alternation where the halite mineral does not precipitate and may indicate that the evaporation is weakened relatively and stagnant in the basin and the basin gains a more dilute character in sedimentation conditions.

Glauberite is the second most common evaporitic mineral in the basin after the halite mineral. Massive glauberitic layers are observed macroscopically with halite, locally anhydrite / gypsum and partly dolomite. Towards the bottom of the sequence, it is observed that the shale bands with thin shale bands are mostly rich in organic matter. Laminated glauberites were seen as alternating layers with anhydrite and magnesitecontaining beds. Visible glauberites are self-shaped, partially discoidal, parallel to the deposition surface. The most common occurrences of glauberites are: $1-$ thin $(20-30 \mathrm{~cm}$ thick) nodular, intestinal bands, alternating with laminal-gypsum; 2- thick (1-4 m) beds with distinctive band are massive, banded and nodular. 3-halite and massive or euhedral crystals (pyramidal, rhombohedral, and zoned) developed, 4- organic material was also observed in the rich shales and on the surface of the shales as secondary fibrous and acicular glauberites.

Halite show a rhythmic alternation, usually a few $\mathrm{mm}$ and somewhere in meter dimension. There are differences in the thickness and morphological shape of halite alternations between drillings. Major halite morphologies have been observed in the following forms: a) large crystals, transparent, self-shaped, growing parallel to the bottom stratification, b) shapes with a euhedral-shaped shear structure and hopper structure, c) light-dark greyish halite or amorphous-euhedral shaped, or in massive form, d) microcrystalline halite, in the cement state between the glauberite crystals.

\section{Acknowledgement}

The project was funded by The Scientific and Technological Research Council of Turkey (TÜBİTAK 114Y629) and the Selçuk University Scientific Research Projects (16401034) support program.

\section{REFERENCES}

[1] Hardie, L.A. The origin of the recent non-marine evaporite deposit of Saline Valley, Inyo Country, California. Geochimica et Cosmochimica Acta, vol. 32, pp 1279-1301, 1968.

[2] Hardie, L.A. Lowenstein, T.K. \& Spencer, R.J. The problem of distinguishing between primary and secondary features in evaporites. In: Schreiber, B.C., Harner (Eds.), Six Symposium on Salt I. The Salt Institute, Alexandria, VA, pp. 11-39, 1985.

[3] Warren, J. K. Evaporites through time: Tectonic, climatic and eustatic controls in marine and nonmarine deposits, Earth Science Reviews, v. 98, pp 217-268, 2010,

[4] Yoldaş, R. Ulukışla (Niğde) Bitümlü şist alanının jeolojik ve ekonomik olanakları, MTA rapor no: 5050, 1973.

[5] Oktay, F. Y. Stratigraphy and Geological evolution of the Ulukışla and Surrounding Area. Geological Bulletin of Turkey, vol. 25, pp 15-23, 1982. 
[6] Demirtaşl1, E., Turhan, N., Bilgin, A. Z. \& Selim, M. Geology of the Bolkar Mountains. In: Tekeli, O. \& Göncüoğlu, M.C. (Eds.), Geology of the Taurus Belt, Proceedings of the International Symposium on the Geology of the Taurus Belt, pp. 125141, 1984.

[7] Göncüoğlu, M. C. Geochronological data from the Southern Part (Niğde Area) of the Central Anatolian Massif: Bulletin of Mineral Research and Exploration Institute of Turkey (MTA), vol. 105/106, pp 111-124, 1986.

[8] Atabey, E. \& Ayhan, A. Niğde-Ulukışla-Çamardı-Çiftehan Yöresinin Jeolojisi, MTA Derleme no: 8064, 1986.

[9] Müller, D.W. \& Mueller, P.A. Origin and age of the Mediterranean Messinian evaporites: implications from Sr isotopes. Earth Planet. Sci. Lett., vol. 107, pp 1-12, 1991. [10] Görür, N. \& Tüysüz, O. Cretaceous to Miocene Palaeogeographic Evolution of Turkey: Implications for Hydrocarbon Potential. Journal of Petroleum Geology, vol. 24, pp 119-146, 2001.

[11] Göncüoğlu, M. C., Turhan, N., Şentürk, K., Uysal, Ş., Özcan, A. \& Iş1k, A. Orta Sakarya'da Nallıhan Sarıcakaya Arasındaki Yapısal Birliklerin Jeolojik Özellikleri. Maden Tetkik ve Arama Derleme Rapor No: 10094, Ankara (yayımlanmamış), 1996. 